\title{
A review on the immune responses against novel emerging coronavirus (SARS-CoV-2)
}

\author{
Ramin Lotfi ${ }^{1,2}$ (1) $\cdot$ Rasoul Nasiri Kalmarzi ${ }^{2} \cdot$ Seyed Askar Roghani ${ }^{3}$
}

Received: 28 February 2021 / Accepted: 23 April 2021 / Published online: 29 April 2021

(c) The Author(s), under exclusive licence to Springer Science+Business Media, LLC, part of Springer Nature 2021

\begin{abstract}
Coronavirus disease 2019 (COVID-19) is a highly contagious disease caused by a newly identified coronavirus called the severe acute respiratory syndrome-coronavirus 2 (SARS-CoV-2) which was initially emerged in Wuhan, China in late December 2019 and then rapidly extended to other countries worldwide. COVID-19 is now known as a pandemic threat to global public health. It possesses a wide spectrum of clinical manifestations, ranging from asymptomatic infection to mild, moderate, and ultimately severe pneumonia accompanied by multi-organ system dysfunction that can cause the death of the afflicted patients. The host immune system plays a critical role in defending against potentially pathogenic microorganisms such as coronaviruses, and it eliminates and eradicates these invading agents by triggering effective immune responses. However, there exists evidence indicating that in critically ill cases of the COVID-19, dysregulated immune responses and hyper-inflammation lead to acute respiratory distress syndrome (ARDS) and multi-organ failure. Achieving a profound understanding of the pathological immune responses involved in the pathogenesis of COVID-19 will boost our comprehending of disease pathogenesis and its progression toward severe form, contributing to the identification and rational design of effective therapies. In this review, we have tried to summarize the current knowledge regarding the role of immune responses against SARS-CoV-2 and also give a glimpse of the immune evasion strategies of this virus.
\end{abstract}

Keywords Coronavirus disease $2019 \cdot$ Innate immunity $\cdot$ ACE2 $\cdot$ Adaptive immunity $\cdot$ SARS-CoV-2

\section{Introduction}

Coronaviruses (CoVs), which belong to the virus family of Coronaviridae, are large enveloped viruses having nonsegmented, single-stranded, and positive-sense RNA genomes (26-32 kb). Generally, these viruses cause respiratory, gastrointestinal, hepatic, and neurologic disorders in birds and mammals, including humans [1]. So far, two life-threatening pandemic outbreaks of CoVs have occurred in the past two

Ramin Lotfi

ramin.lotfi1370@gmail.com; ramin.lotfi@muk.ac.ir

1 Cellular and Molecular Research Center, Research Institute for Health Development, Kurdistan University of Medical Sciences, PO-Box: 6617713446, Sanandaj, Iran

2 Lung Diseases and Allergy Research Center, Research Institute for Health Development, Kurdistan University of Medical Sciences, Sanandaj, Iran

3 Clinical Research Development Center, Imam Reza Hospital, Kermanshah University of Medical Sciences, Kermanshah, Iran decades, including the severe acute respiratory syndromeCoV (SARS-CoV) in 2002-2003 and the Middle East respiratory syndrome-CoV (MERS-CoV) in 2011 [2]. In late December 2019, a new and highly pathogenic virus, which was initially named novel CoV 2019-nCoV and later renamed to SARS-CoV-2, causing a clinical syndrome with pneumonia-like symptoms termed coronavirus disease 2019 (COVID-19) emerged in Wuhan, a city in the Hubei Province of China [3]. Through person-to-person transmission, COVID-19 has quickly spread to other regions of China and other countries all over the world [4]. Importantly, COVID19 has become a very great threat to global public health as it has led to more than 143 million confirmed cases and over 3 million deaths until April 21, 2021. More importantly, these numbers are rising increasingly [5]. The clinical manifestations of COVID-19 illness were found to be widely varied, ranging from asymptomatic infection to mild, moderate, and ultimately severe pneumonia accompanied by multi-organ system dysfunction that can cause the death of the afflicted patients [2]. Studies have reported that the early most prevalent symptoms of COVID-19 disease are 
fever, dry cough, and myalgia, or fatigue, whereas additional symptoms, including headache, hemoptysis, sputum generation, lymphopenia, normal or reduced leukocyte count, radiographic evidence of pneumonia, diarrhea, and dyspnea, are also observed in some cases [2, 6-8]. Thus, these findings increasingly indicate that the symptoms of COVID-19 disease are similar to those of SARS-CoV and MERS-CoV infections [9]. Genomic analysis indicated that SARS-CoV-2 has more than 95\% homology with the bat $\mathrm{CoV}$ and approximately $79 \%$ similarity with the SARS-CoV [10]. The invasion, attachment, and entry of SARS-CoV-2 into the human host cells are mediated by its surface spike (S) glycoproteins, which are located on the envelope of the virus. As the most immunogenic part of the virus, S glycoproteins contain two domains of S1 and S2 [11, 12]. Molecular modeling investigations have revealed a high similarity of the receptor-binding domain (RBD) of S glycoproteins in SARS-CoV and SARS-CoV-2 [11]. Interestingly, the RBD in the $\mathrm{S} 1$ domain of $\mathrm{S}$ glycoproteins binds to transmembrane angiotensin-converting enzyme 2 (ACE2) receptors, which are not only expressed on the alveolar epithelial type II cells at very high levels (representing $83 \%$ of target cells expressing ACE2), but also found on the gut, vascular endothelium, kidney, and heart cells [13]. On the other hand, the S2 domain fulfills the membrane fusion of virus-cell and viral entry with higher affinity [12]. In addition to ACE2, a host cellular protease termed type 2 transmembrane serine protease (TMPRSS2) also contributes to cell entry of SARS-CoV-2 through the S glycoproteins (Fig. 1) [14]. Furthermore, heparan sulfate proteoglycans (HSPGs) have been reported to act as the nonspecific receptors for beginning the infectivity of CoVs and a variety of viruses. Noteworthy, a wide range of the host membrane proteases, including TMPRSS4 besides TMPRSS2 and likely furin, extracellular proteases like trypsin, elastin, plasmin, and factor Xa protease, as well as cathepsins, may also be implicated in the binding and subsequent cell entry of SARS-CoV-2. It is worth considering that the replication and maturation of the virus inside the host cells markedly depend on two viral proteases, namely, the main protease (Mpro) and the papain-like protease (PLpro) [15]. Recent evidence indicates above tenfold higher binding affinity of SARS-CoV-2 for ACE2 than SARS-CoV; however, this affinity is higher compared to the threshold needed for virus infectivity [16]. Given the rapidly increasing outbreak of COVID-19, this review intends to summarize the current knowledge concerning the role of the immune system in the pathogenesis of this ominous disease and also gives a side glance at immune evasion strategies of its causative virus, SARS-CoV-2.

\section{Immune responses against SARS-CoV-2}

Since SARS-CoV-2 is a new member of the Coronaviridae family, its pathogenesis is poorly understood. However, as explained above, both SARS-CoV-2 and SARS-CoV have the same cell entry mechanism. Furthermore, SARS-CoV-2 has a high similarity with both the SARS-CoV and MERS$\mathrm{CoV}$. Accordingly, knowing the pathogenic mechanisms of these two viruses can give us a large amount of useful information concerning the pathogenesis of SARS-CoV-2 [17]. Continuing this article, we have tried to explain responses of the immune system, including innate and adaptive immunity, against SARS-CoV-2.

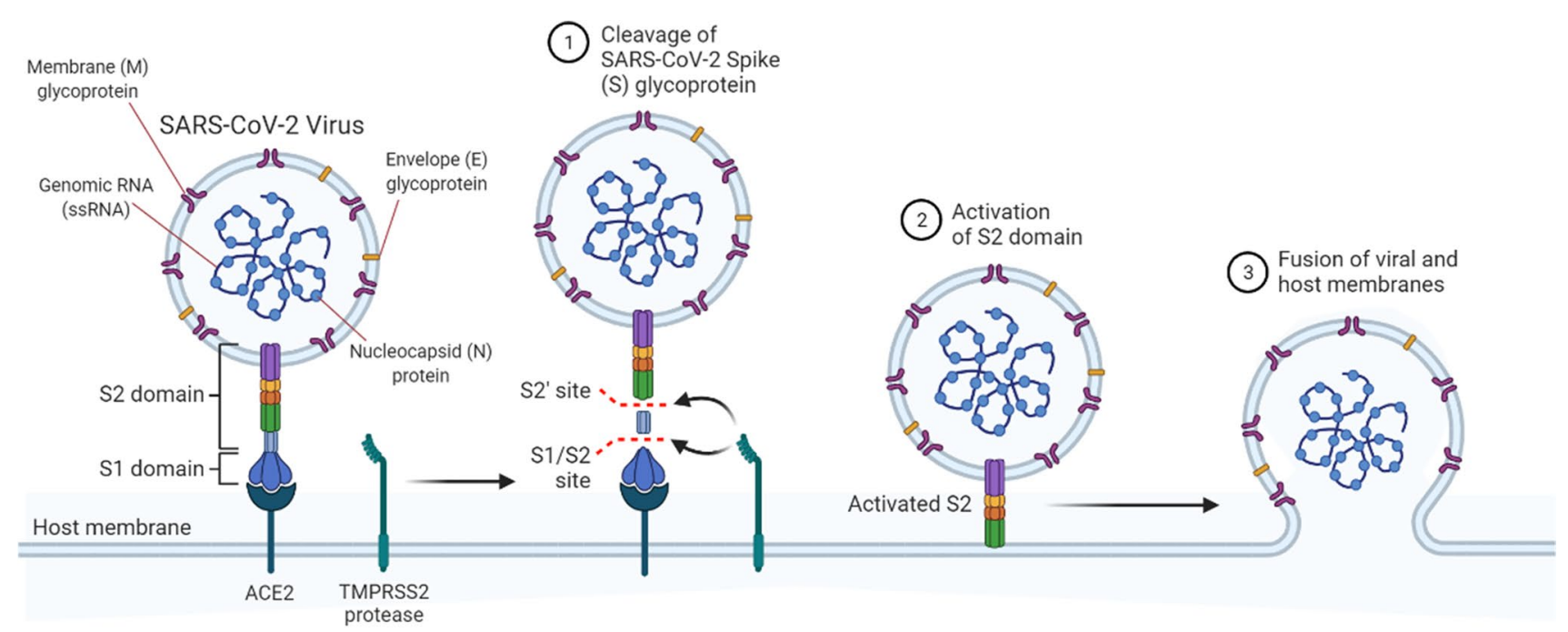

Target cell

Fig. 1 The viral entry mechanism of SARS-CoV-2 into the host cell (the figure was made with BioRender) 


\section{The role of innate immunity against SARS-CoV-2}

Although innate immunity as the first line of defense against invading pathogens plays a critical role in combating the SARS-CoV-2 and restraining the dissemination of its infection in the host body, only limited information is currently available concerning the responses of the host innate immune system in patients with COVID-19. Following the binding of the superficial $\mathrm{S}$ glycoproteins of the virus to the ACE2 receptor and subsequently membrane fusion of the virus into host cells leading to the viral entry, the RNA genome of the virus is exported from the envelope into the cytoplasm and the translation process of the viral proteins initiates. Afterward, the replication of the viral RNA genome is completed, and by combining part of the host cell membrane in the new envelope of the virus, finally, the new viral particles are built up and then bud from the infected cells without directly lysing them [17]. Pulmonary epithelial cells are one of the first innate immune cells infected with SARS$\mathrm{CoV}-2$, and after being infected, they produce interleukin (IL)-8, which functions as a chemoattractant cytokine for neutrophils and $\mathrm{T}$ cells. In essence, alveolar macrophages and neutrophils besides pulmonary epithelial cells initially trigger the innate immune responses to the virus [18]. The immune cells identify the invading viruses through virusderived pathogen-associated molecular patterns (PAMPs), which bind to and activate pattern recognition receptors (PRRs) in/on immune cells, thereby causing the initiation of the antiviral responses. The PAMPs of CoVs are in the form of viral genomic RNA or the intermediates during viral replication like double-stranded RNA (dsRNA), which are sensed by PRRs such as endosomal toll-like receptors (TLRs), including TLR7 and TLR3, or the cytosolic RNA sensors like retinoic acid-inducible gene I (RIG-I) and melanoma differentiation-associated gene 5 (MDA5) [19]. Endosomal TLR7, which is expressed in monocytes, macrophages, and dendritic cells (DCs), recognizes viral singlestranded RNA (ssRNA) and, thereby, can lead to the activation of several signaling pathways and transcription factors (TFs). These include Janus kinase/signal transducer and activator of transcription (JAK/STAT), nuclear factor kappa B (NF- $\mathrm{KB}$ ), activator protein 1 (AP-1), interferon response factor 3 (IRF3), and IRF7 [20]. The resultant signaling cascade from these pathways in the infected cells leads to enhancing the production of pro-inflammatory cytokines, including IL-1, IL-6, monocyte chemoattractant protein-1 (MCP-1), tumor necrosis factor (TNF)- $\alpha$, macrophage inflammatory protein (MIP)-1A, and type 1 interferons (IFNs) [21, 22]. Moreover, IL-8 produced by pulmonary epithelial cells causes the neutrophils to be instantly recruited toward the areas of infection, where neutrophils kill the viruses by several mechanisms, including neutrophil extracellular traps (NETs), oxidative burst, and production of antimicrobial peptides like defensins [23]. Recent studies in COVID19-infected patients of Wuhan City have illustrated enhanced total neutrophils, serum IL-6, C-reactive protein (CRP), and decreased total lymphocytes [24-26]. Besides that, enhanced neutrophils and reduced lymphocytes were intimately associated with illness severity and death [25]. Also, increased plasma levels of several innate cytokines, including MCP-1, TNF- $\alpha$, interferon (IFN)- $\gamma$ inducible protein-10 (IP-10), and MIP-1A, have been reported in COVID-19 patients requiring the intensive care unit (ICU) [2]. Similar to COVID19 infection, the early increment of serum levels for proinflammatory cytokines was also observed in SARS-CoV and MERS-CoV infections, suggestive of potential similar cytokine storm-induced illness severity [27, 28]. In addition to cytokine storm, dysregulated or excessive immune responses and macrophage activation syndrome play a major role in the pathogenesis and exacerbation of COVID-19 [26, 29-31]. It was also found that more lung tissue damage and severe pneumonia in patients with severe forms of COVID19 are mainly owing to hyper-inflammation, not a direct detrimental effect of the virus itself [30]. These clinical characteristics generally propose the probable involvement of highly pro-inflammatory conditions in the intensification and progression of COVID-19 illness.

Effective responses of the innate immunity against viral infections strongly depend on the production of type 1 IFNs and their downstream signaling pathways, which are increasingly imperative for controlling viral replication and subsequently inducing effective responses of the adaptive immunity. SARS-CoV-2, similar to SARS-CoV, seems to use ACE2 as a specific receptor for entry into the host cells, whereas MERS-CoV utilizes transmembrane dipeptidyl peptidase (DPP)-4 as an entry receptor [24]. Notably, an important feature of SARS-CoV-mediated pathogenesis is that SARS-CoV directly infects macrophages and T cells [31]. However, it is still uncertain that SARS-CoV-2 infects which immune cells. Indeed, it has been reported that only limited numbers of monocytes/macrophages in the lung express ACE2 [3]. These findings raise the possibility of the existence of additional receptors or additional cellular entry mechanisms like antibody-dependent enhancement (ADE) leading to the increment of SARSCoV-2 entry into host immune cells (Fig. 2).

Both SARS-CoV and MERS-CoV apply multiple strategies to interfere with the signaling pathways leading to the production of type 1 IFNs and/or the signaling pathways downstream of IFN receptors (IFNRs), thereby inhibiting the response of type 1 IFNs to these viral infections. Of note, the mentioned strategy is closely associated with illness severity [32]. By ubiquitinating and subsequent proteasomal degradation of RNA sensor adaptor molecules like mitochondrial antiviral signaling protein (MAVS) and TNF-receptor-associated factor 3/6 (TRAF3/6) and suppressing the nuclear 


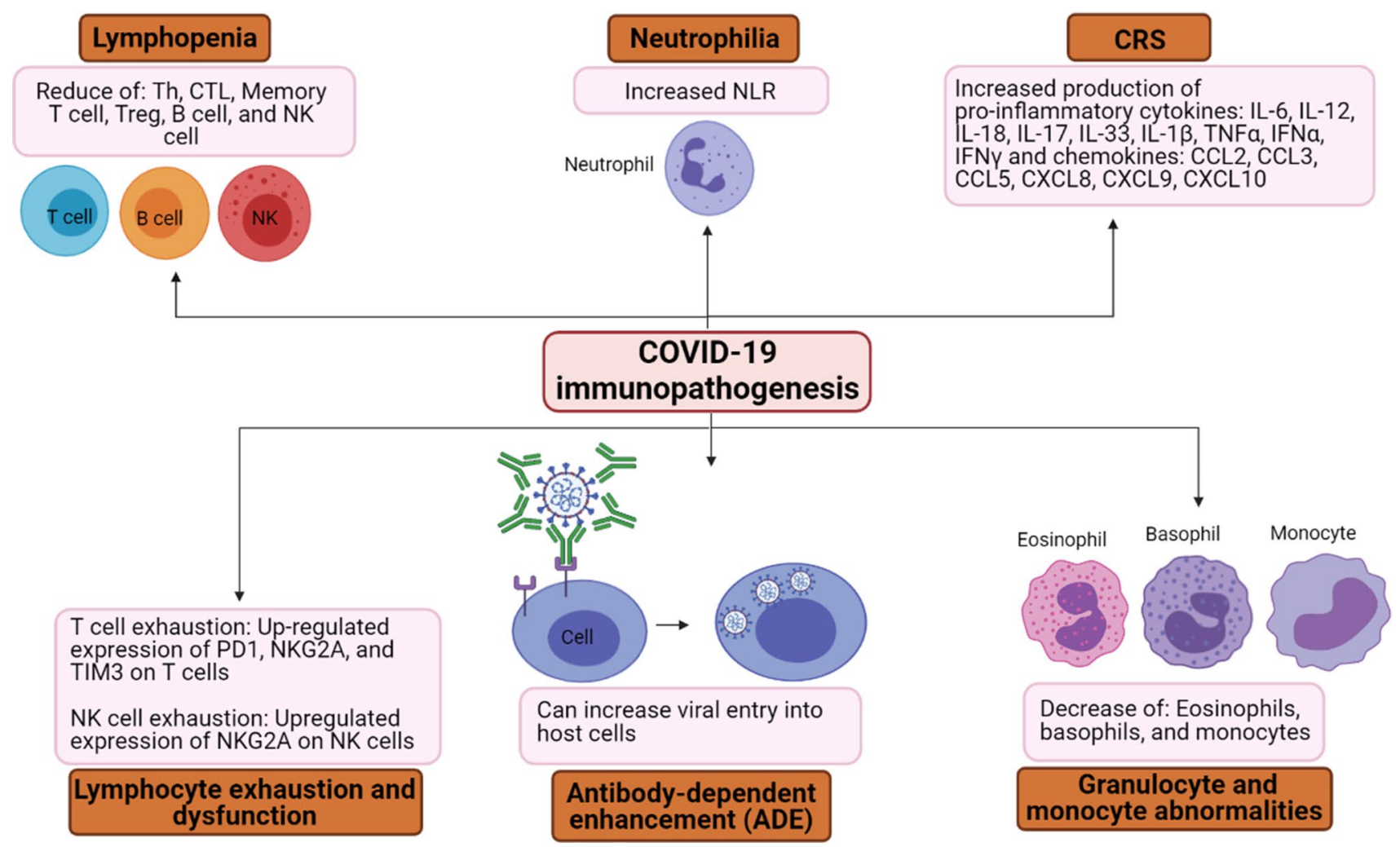

Fig. 2 The immunopathogenesis of COVID-19. The major events implicated in the immunopathogenesis of COVID-19 and the dysregulation of immune response in these patients encompass lymphopenia, increased neutrophil-to-lymphocyte ratio (NLR), cytokine release syndrome (CRS), lymphocyte exhaustion and dysfunction, antibodydependent enhancement (ADE), and abnormalities of monocytes and

translocation of IRF3, SARS-CoV interferes with the signaling cascades downstream of RNA sensors inducing the type 1 IFN production [33]. In addition to some of these strategies, MERS-CoV also reduces IFN-stimulated gene (ISG) expression via activating repressive histone modifications [33]. Moreover, these two viruses reduce STAT1 phosphorylation, consequently causing the inhibition of IFN signaling upon the production of type 1 IFNs [34]. Both structural (like $\mathrm{M}$ and $\mathrm{N}$ ) and non-structural proteins (ORF; open reading frame) of these viruses are implicated in modulating the host type 1 IFN response [20]. According to the overall genomic similarity of SARS-CoV-2 with SARS-CoV or MERS-CoV ( 79\% and 50\%, respectively), it is partly speculated that SARS-CoV-2 uses similar strategies to modulate the host innate immune response, particularly in dampening the type 1 IFN response. Nevertheless, additional novel mechanisms may perhaps also be involved [20]. Previous studies have shown that in the severe or fatal cases of SARS-CoV or MERS-CoV infection, enhanced infiltration of neutrophils and monocyte-macrophages are consistently seen $[31,35]$. Also, using a murine SARS-CoV model, it has been found that dysregulated response of type 1 granulocytes. It is worth considering that lymphopenia is a key finding in the majority of patients with COVID-19, particularly in those patients with a severe phenotype. PD1, programmed cell death-1; TIM3, T cell immunoglobulin and mucin domain-containing protein-3; NK cell, natural killer cell (the figure was made with BioRender)

IFN and inflammatory monocyte-macrophages are the leading cause of fatal pneumonia [32]. Alveolar macrophages expressing supplant fatty acid binding protein-4 (FABP4) and the ficolin-1 expressing monocyte-derived macrophages have been indicated to be the predominant macrophage subset in the lungs of patients suffering acute respiratory distress syndrome (ARDS) [36]. The mentioned cells are potentially involved in developing uncontrollable inflammatory responses and generating a wide range of cytokines and chemokines [37]. These findings verify the motion of inflammatory monocyte-macrophages into the lung tissue and other organs that are infected with the SARS-CoV-2. The main events implicated in the immunopathogenesis of COVID-19 were summarized in Fig. 2.

\section{The role of adaptive immunity against SARS-CoV-2}

The adaptive immune system, also known as the acquired or specific immune system, responds to pathogens in an antigen-specific fashion to beget protective immunity. This system has two major arms, including cellular immunity, which is mediated by T cells, and humoral immunity, which 
is mediated by B cells (antibody-generating cells) [38]. During viral infections, the effective response of the adaptive immunity, entailing both cellular and humoral immunity, is crucial to eliminate the viral particles from the host body, preclude the illness progression to severe stages, and ultimately recover the affected patients [39]. In general terms, helper $\mathrm{T}$ lymphocytes (Th; also known as $\mathrm{CD} 4^{+} \mathrm{T}$ cells) function as the pivotal players participating in the adaptive immune response triggered following viral infections [40]. After the virus identification, processing, and representation of the viral antigens by APCs to $\mathrm{CD} 4^{+}$and $\mathrm{CD} 8^{+} \mathrm{T}$ cells, APCs generate the cytokine microenvironment dictating the direction of T cell responses [41]. Indeed, Th cells are vital for producing different cytokines leading to inducing the recruitment of immune cells, as well as priming both $\mathrm{CD} 8^{+}$ $\mathrm{T}$ cells and B cells, whereas cytotoxic T lymphocytes (CTLs; also known as $\mathrm{CD}^{+} \mathrm{T}$ cells) are indispensable for directly assailing and killing the virus-infected cells through perforin and granzyme cytotoxic proteins-containing granules [42]. It is worth noting that the aforementioned cells exert critical roles in defending against viral infections [42]. Notably, Th and T follicular helper (Tfh) cells activate B cells to produce virus-specific neutralizing antibodies, which exert a protective role by limiting the COVID-19 infection at a later phase and restraining reinfection in the future [43]. It seems that high-affinity neutralizing antibodies can recognize the particular domains on the viral $\mathrm{S}$ glycoprotein by using their fragment antigen-binding (Fab) regions, thereby blocking virus attachment and entry to host cells expressing ACE2 receptor [44]. Also, these antibodies can interact with other immune cells like phagocytes, NK cells, and complement systems, thus begetting a bridge between innate and adaptive immune systems [45]. Evidence shows that producing antibodies and seroconversion takes place in the first 2 weeks after the onset of COVID-19 symptoms [46]. Similar to other viral infections, specific immunoglobulin $\mathrm{M}(\operatorname{IgM})$ is the first defense to emerge and fades after a short time, whereas specific IgG functions as an effective and long-standing defense against SARS-CoV-2. As a result, neutralizing IgG antibodies exert a significant role in the recovery of patients and controlling the infection [47, 48]. According to a recent study on antibody responses in COVID-19 patients, the majority of the afflicted patients produce virus-specific IgM and/or IgG antibodies in the days following infection [49]. Moreover, the study of Wen et al. has shown that in the peripheral blood mononuclear cells (PBMCs) of COVID-19 patients during their recovery period, the count of naïve B cells is remarkably reduced, while the count of plasma cells is markedly increased [50]. Several lines of evidence have depicted that high levels of SARS-CoV-2 virus-specific antibodies are associated with more viral neutralization in vitro and are inversely associated with viral load in infected patients [51-53]. Nevertheless, these higher levels of virus-specific antibodies are also correlated with more severe clinical phenotypes in patients, suggestive of being insufficient a potent antibody response alone to prevent severe illness [51,53-55]. Similarly, in the prior SARS-CoV epidemic, higher levels of virus-specific neutralizing antibodies were also reported in dead patients compared to the meliorated patients [56]. The mechanism by which antibody responses to CoVs cause organ damage and disease progression may be explained by the phenomenon of antibody-dependent enhancement (ADE), in which non-neutralizing antibodies generated by plasma cells can boost virus entry into the Fc-receptor (FCR) expressing cells (especially monocytes and macrophages), thereby leading to the activation of inflammatory responses in these cells (Fig. 2) [57]. Based on the recent investigations, the ADE phenomenon has been reported in the case of SARS-CoV and MERS-CoV infections [58-60]. Thus, these findings along with those recently published indicate the association between increased antibody response and poor outcome of patients suffering COVID-19 [53, 61]. Noteworthy, longlived plasma cells and memory B cells, which are formed during the primary infection, constitute two main arms of B cell memory. They cause extended immunity against reinfection. Through generating new high-affinity plasma cells, memory B cells can rapidly respond to reinfections, leading to begetting long-lasting protection. Therefore, longlasting protection is the result of inducing long-lived plasma cells and memory B cells [62]. A recent study in convalescent COVID-19 patients indicated that the serum levels of anti-SARS-CoV-2 IgG antibodies are markedly reduced 6 months following infection. Besides, in the majority of these patients, SARS-CoV-2-specific T and/or memory B cell responses were developed with time and retained at a relatively high level 6-8 months after the initiation of the symptoms, suggesting that protective adaptive immunity after natural SARS-CoV-2 infection may persist for at least 6-8 months, irrespective of illness severity [63].

Amongst the subsets of Th cells, Th1 cells secreting pro-inflammatory cytokines, including IL-2, TNF- $\alpha$, and IFN- $\gamma$, are the most main cells involved in the adaptive immune responses to viral infections [20]. Generated proinflammatory cytokines by Th cells are regulated through the nuclear factor- $\mathrm{kB}(\mathrm{NF}-\mathrm{\kappa B})$ signaling pathway [41]. Similar to SARS-CoV [64] and MERS-CoV [65] infections, SARS$\mathrm{CoV}-2$ is thought to induce a Th1-type immune response [66]. The results of the first survey conducted on COVID-19 patients displayed that low expressions of IFN- $\gamma$ and TNF- $\alpha$ in $\mathrm{CD}^{+}{ }^{+} \mathrm{T}$ lymphocytes, as well as high levels of granzyme $\mathrm{B}$ and perforin in $\mathrm{CD} 8^{+} \mathrm{T}$ cells, are associated with disease severity. Additionally, the frequency of the exhausted subset $\left(\mathrm{PD}{ }^{+}{ }^{+} \mathrm{TLA}_{4}{ }^{+} \mathrm{TIGIT}^{+}\right)$of $\mathrm{CD} 8^{+} \mathrm{T}$ cells was strikingly higher in the severe COVID-19 cases, in comparison with mild COVID-19 cases and healthy people [67]. In line with 
this study, another research revealed lower frequencies of $\mathrm{CD}^{+}{ }^{+} \mathrm{T}$ cells generating IFN- $\gamma$ in severe cases of COVID19 infection $[68,69]$. These findings indicate that functional defects of $\mathrm{CD}^{+} \mathrm{T}$ cells and exhaustion of $\mathrm{CD} 8^{+} \mathrm{T}$ cells are associated with the severe outcome of COVID-19 illness.

Previously, it has been shown that infecting T cells with SARS-CoV is directly contributed to developing lymphopenia, as well as atrophy of the lymphoid tissue and spleen in patients with SARS-CoV infection [70]. Compatible with this finding, lymphopenia is also seen in MERS-CoV cases, although its degree is lesser relative to SARS-CoV patients [71]. In addition, the study of Chu et al. in 2016 indicated that MERS-CoV possesses an unusual capacity to assault $\mathrm{T}$ cells of peripheral blood and some lymphoid organs, as well as induce the activation of both intrinsic and extrinsic apoptosis pathways, which might partially be contributed to developing lymphopenia in afflicted patients and also high pathogenicity of the virus [72]. Recent investigations have indicated a striking lymphopenia in patients suffering COVID-19, but this issue that which factors influence the lymphopenia has yet to be identified. Some studies propose that SARS-CoV-2 may perhaps destruct $\mathrm{T}$ cells, thereby suppressing the cellular arm of adaptive immunity [2, 40, $73,74]$. Overall, several suggested mechanisms for lymphopenia in COVID-19 cases are as follows: (a) Direct infecting of lymphocytes by the virus may perhaps lead to the death of these cells; (b) the virus can harm the several target organs, like the thymus and bone marrow, leading to longterm abnormal function of these organs; (c) vast generation of pro-inflammatory cytokines may perhaps result in lymphocyte apoptosis; (d) infiltrated lymphocytes are snared in virus-infected tissues [75].

The number of $\mathrm{CD} 8^{+} \mathrm{T}$ cells was found to be diminished during COVID-19 infection. Besides, the count of memory $\mathrm{CD}^{+} \mathrm{T}$ cell and regulatory $\mathrm{T}$ cell (Treg cell) was considerably decreased in severe COVID-19 cases. Also, these observations were coupled with the reduced $\mathrm{CD} 4^{+}$and $\mathrm{CD} 8^{+} \mathrm{T}$ cell count in lymph nodes. Spleen and lymph nodes have been described as atrophic in COVID-19-suffering patients, highlighting the role of SARS-CoV-2 in promoting cell destruction [76]. Consistent with these findings, the recent study of Wang et al. revealed a meaningful reduction of count for both $\mathrm{CD} 4^{+}$and $\mathrm{CD} 8^{+} \mathrm{T}$ cells in severe COVID19 cases. Although the count of $\mathrm{CD} 8^{+} \mathrm{T}$ cells reduced, the ratio of HLA-DR expression on these cells was over 35\% in severe COVID-19 cases compared to those with moderate illness [74]. According to evidence, HLA-DR expression on $\mathrm{T}$ cells is recognized as an activation marker, and $\mathrm{CD} 8^{+} \mathrm{T}$ cells expressing HLA-DR are regarded as Treg cell subset, which use the CTLA-4 signaling pathway to exert their inhibitory action on neighboring T cells [77]. Thus, a decreased number of $\mathrm{CD} 8^{+}$Treg cells might be implicated in deteriorating the condition of severe COVID-19 cases compared to those with moderate illness. Moreover, the study evaluating the association of lymphocyte count with the outcome of COVID-19 cases has proposed that enhanced $\mathrm{T}$ cell count to normal levels has a potential effect on the virus's clearance, and it may also be considered an indicator of the recovery for COVID-19-suffering patients [78].

Analysis of lung autopsy for deceased patients from COVID-19 illness revealed that the occurrence of acute respiratory failure (ARF) is resulting from the over-activation of infiltrated immune cells, as evidenced by the formation of edema and hyaline membrane coupled with the inflammatory influx of immune cells [79]. Besides that, higher plasma concentrations of TNF- $\alpha$, IL-2, IL-7, IL-10, G-CSF, IP-10, MIP- $1 \alpha$, and MCP-1 in severe COVID-19 cases relative to those with moderate disease suggest that an excessive generation of inflammatory cytokines and chemokines could impair the pulmonary function [80]. In a murine model of SARS-CoV infection, evacuation of $\mathrm{CD}^{+} \mathrm{T}$ cells has been found to not affect the viral replication or clearance. Nonetheless, $\mathrm{CD}^{+}{ }^{+} \mathrm{T}$ cell evacuation is associated with diminished recruitment of lymphocytes into the lung, as well as reduced generation of cytokines and antibodies, events that cause immune system-mediated severe pneumonitis and delayed clearance of SARS-CoV from the lungs [81].

Recent reports have shown that the ARDS, the common immunopathological event between the three known coronavirus diseases, including SARS-CoV, MERS-CoV, and SARS-CoV-2 infections, leads to low oxygen saturation levels and hence is one of the leading causes of mortality in COVID-19-suffering patients [2, 79]. One of the major mechanisms responsible for developing ARDS is cytokine release syndrome (CRS: also known as cytokine storm syndrome (CSS)) [17, 82]. CRS is a fatal uncontrolled systemic inflammatory response to infections, leading to over-activation of immune effector cells and consequently, producing immense amounts of pro-inflammatory cytokines and chemokines in SARS-CoV infection [17, 83]. Clinically, CRS is characterized by hyperferritinemia, hyper-inflammation, hemodynamic instability, overwhelming systemic inflammation, and multi-organ failure, and it results in death if remained untreated [84]. Furthermore, several lines of evidence analyzing cytokine profiles in patients with COVID19 proposed that the CRS is directly associated with multiorgan failure, lung damage, and unfavorable prognosis of severe cases of COVID-19 [2, 69, 85-88]. Studies have also shown that the SARS-CoV-2 virus selectively induces the production of high amounts of IL-6 and leads to lymphocyte exhaustion $[82,89]$. Considering that IL-6 is the most abundant reported cytokine to be increased in patients with COVID-19 and that heightened levels of IL- 6 are associated with higher mortalities, hence, tocilizumab (TCZ), a recombinant humanized monoclonal antibody against the IL-6 receptor that inhibits the intercellular signaling in 
cells expressing GP130, is a candidate drug to be utilized for managing and also mitigating the cytokine storm accompanying COVID-19 infection [90]. Altogether, the adaptive immune system which is affected by the SARS-CoV-2 virus is attempting to eliminate the virus through cytokine storm and hyperinflammatory responses, which these events themselves result in ARDS, multi-organ failure, and even death. On the other hand, SARS-CoV-2 is a cytopathic virus, causing the induction of death and damage of virus-infected cells and tissues as a portion of the replicative cycle for the virus [91].

\section{Immune evasion strategies of SARS-CoV-2}

The onset of the COVID-19 illness usually accompanies a 2-14-day incubation period, indicating the potential ability of the virus to escape the immune system and to multiply in infected host cells $[92,93]$. Investigations have shown that members of the CoVs family shrewdly suppress the humoral immune responses by acquiring genetic mutations that lead to escaping host identification [93, 94]. The results of RNA sequencing revealed a high genetic similarity of SARS-CoV-2 with other members of the betacoronavirus family, so almost all of them show a similar immune evasion strategy $[10,95]$. Due to the above and the novelty of the SARS-CoV-2, focusing on other CoVs may help us better understand the mechanisms by which the SARS-CoV-2 escapes the immune system [20]. In this part, we are going to review the mechanisms and ways in which the SARS$\mathrm{CoV}-2$ escapes the host's immune system and causes damage to the host tissues.

The first line of defense against the viruses entering the body is the innate immune system and its cells, which play an important role in identifying and controlling viral infections (such as CoVs) and subsequently activate the acquired immunity [96]. IFNs are regarded as the key factors involved in regulating the antiviral innate response to $\mathrm{CoVs}$ infection. SARS-CoV and MERS-CoV can cleverly inhibit this defense mechanism in various ways. These viruses suppress the type I IFN response at various stages, including IFN production and signaling [97, 98]. By ceasing the phosphorylation of STAT1 and restraining the host gene expression through inactivating the translational function of ribosomes, non-structural protein 1 (Nsp1) restrains the IFN signaling in cells being infected with the SARS-CoV [99]. In addition, recent evidence shows that the induction of type I IFNs production acts as a beneficial response in the SARS-CoV-2 infection [100]. Indeed, CoVs can hide from host cytoplasmic (e.g., RIG-1 and MDA-5) and endosomal (e.g., TLR 3/7) sensors-dependent identification. As a result, the IRF3 gene is not stimulated, and this, in turn, causes inhibiting the expression and production of the type 1 IFNs [20, 24, 101,
102]. It has also been reported that SARS-CoV and MERSCoV have a special ability to produce double-membrane vesicles empty of PRR, which allows the virus to multiply in these vesicles away from being detected by the immune system [103]. Additionally, the nucleocapsid (N) protein of SARS-CoV and MERS-CoV has been shown to play a significant role in the life cycle of these viruses and also host-viral interactions. The SARS-CoV N protein interferes with TRIM25-based RIG-1 ubiquitination, thereby leading to the inhibition of IFN production. Besides, the interaction of the MERS-CoV N protein with the TRIM25 restrains the signaling of RIG-1 and thus leading to the blockade of IFN production [104]. Another pathway that SARS-CoV and MERS-CoV can block IFN production in infected cells is by targeting the IFNAR signaling. It has been found that some molecules of these viruses, including Nsp1, ORF6, and ORF3b, suppress IFNAR signaling by inhibiting the STAT1 $[99,105,106]$. Besides, the M, ORF4a, ORF4b, and ORF5 proteins of MERS-CoV, as well as Nsp13, Nsp14, Nsp15, and ORF6 of SARS-CoV-2, have been reported to be potent antagonists for IFNs [107, 108]. The SARS-CoV ORF9b also restrains the innate immune responses via affecting the mitochondrial activity and the MAVS/TRAF3/TRAF6 signalosome [109]. CoVs can also inhibit TLR signaling. For instance, the papain-like protease (PLpro) of SARS$\mathrm{CoV}$ acts as an antagonist to the TLR7 signaling pathway, thereby inhibiting the production of type I IFNs [110, 111]. Furthermore, MERS-CoV spike (S) glycoprotein can activate the DPP4 receptor expressed on macrophages, thereby suppressing their responses via boosting the expression of the negative regulator of TLR signaling, namely IRAK-M, and production of IL-10, as well as decreasing TNF- $\alpha$ and IL-6 cytokine generation [112].

Moreover, studies have shown the functional defects in NK cells during SARS-CoV-2 infection [113]. The validity of this finding is strengthened by reducing the expression of the killer immunoglobulin-like receptor (KIR) and CD16 in peripheral blood cells [114]. Research has also shown that $\mathrm{CoVs}$ can disrupt the acquired immunity by acting on the cells of the innate immunity. It has been indicated that macrophages or DCs infected by MERS-CoV have the diminished expression of major histocompatibility complex class I (MHC-I) and MHC-II molecules, and this, in turn, causes decreased activation of $\mathrm{T}$ cells [115]. Besides that, SARS-CoV2-infected DCs show functional impairment in the differentiation and maturation, which leads to the inhibition of $\mathrm{T}$ cell-mediated responses, thereby facilitating the viral evasion of the adaptive immune response [116]. Also, infection with SARS-CoV-2 can downregulate the expression of MHC-II on B cells, thereby reducing the activation of acquired immunity [117].

The emerging of new variant strains of SARS-CoV-2 has more recently been reported in different regions of the 
globe: B.1.1.7 in the UK (October 2020), B.1.351 in South Africa (October 2020), and P.1 in Brazil (December 2020). These variants have acquired mutations in the ACE2 interaction surface of the RBD [118]. It is important to mention that a successful antibody response against SARS-CoV-2 largely depends on the targeting of one specific epitope; for instance, the spike or the RBD of the spike. Mutations in these epitopes cause antibodies to be unable to efficiently recognize the virus and, thus, these new variants escape the antibody responses and can infect other individuals, regardless of their immunity to the initial strain [119]. Recent evidence indicates that several mutations in the RBD of the spike, including E484K, K417N, and N501Y in B.1.351 variant, cause firmer connecting to ACE2 and widespread escape from neutralization by monoclonal antibodies. Although antibody responses to the new variants may not be capable of preventing infection, they may dampen disease severity. Moreover, mutational changes may not disrupt the response of $\mathrm{T}$ cells to the spike, and these cells may be able to limit the spread of the viral infection to the lower respiratory system and preclude severe disease [118].

\section{Conclusions}

In conclusion, the ongoing pandemic of the COVID-19 has killed more than 3 million people around the world until now and has become a very serious threat to the health of the global people. Besides, it has strikingly impaired the normal lives of most people worldwide. Thus, it is of highly great importance to understand the role of the immune responses in the pathogenesis of this deadly infectious disease and how SARS-CoV-2 escapes the immune responses. Although the immune system is crucial to fighting and defending against viral infections, including the SARS-CoV-2 virus, triggering dysregulated and hyperinflammatory immune responses can be potentially detrimental and lead to begetting severely critical conditions. According to all achieved findings from the performed studies, it can be said that high levels of inflammatory cytokines, lymphopenia, and $\mathrm{CD} 8^{+} \mathrm{T}$ cell exhaustion in critically ill patients with COVID-19 cause their immune system to be severely damaged and become incompetent. The damaged immune system is then tried to compensate for its disabilities by releasing massive amounts of inflammatory cytokines and chemokines, which could potentially result in developing ARDS and multi-organ dysfunction. On the other hand, SARS-CoV-2 evades the immune system by applying multiple strategies. Notably, through the disruption of the normal immune responses, SARS-CoV-2 causes an impaired immune system and developing uncontrollable inflammatory responses in severe and critical cases of COVID-19. Altogether, it seems that the immune system acts as a double-edged sword in fighting SARS-CoV-2.
Abbreviations COVID-19: Coronavirus disease 2019; SARSCoV-2: Severe acute respiratory syndrome-coronavirus 2; ARDS: Acute respiratory distress syndrome; CRS: Cytokine release syndrome; ACE2: Angiotensin-converting enzyme 2; TMPRSS2: Type 2 transmembrane serine protease

Acknowledgements Effective, instructive, and valuable comments provided by the respected reviewers and editor are gratefully acknowledged.

Author contribution R.L. conceived of the paper; R.L. and S.A.R. wrote and edited the paper; R.L., R.N.K., and S.A.R. collected the published papers; and R.L., R.N.K., and S.A.R. critically revised the paper. All authors have read and approved the final paper.

\section{Declarations}

Conflict of interest The authors declare no competing interests.

\section{References}

1. Glass WG, Subbarao K, Murphy B, Murphy PM. Mechanisms of host defense following severe acute respiratory syndrome-coronavirus (SARS-CoV) pulmonary infection of mice. J Immunol. 2004;173:4030-9. https://doi.org/10.4049/jimmunol.173.6.4030.

2. Huang C, Wang Y, Li X, Ren L, Zhao J, Hu Y, et al. Clinical features of patients infected with 2019 novel coronavirus in Wuhan. China Lancet. 2020;395:497-506. https://doi.org/10. 1016/S0140-6736(20)30183-5.

3. Zhu N, Zhang D, Wang W, Li X, Yang B, Song J, et al. A novel coronavirus from patients with pneumonia in China, 2019. N Engl J Med. 2020;382:727-33. https://doi.org/10.1056/NEJMo a2001017.

4. Amrane S, Tissot-Dupont H, Doudier B, Eldin C, Hocquart M, Mailhe $\mathrm{M}$, et al. Rapid viral diagnosis and ambulatory management of suspected COVID-19 cases presenting at the infectious diseases referral hospital in Marseille, France, - January 31st to March 1st, A respiratory virus snapshot. Travel Med Infect Dis. 2020;36:101632. https://doi.org/10.1016/j.tmaid.2020.101632.

5. COVID Live Update: $143,543,965$ cases and 3,057,546 deaths from the coronavirus-Worldometer [Internet]. [cited $2021 \mathrm{Apr}$ 21]. Available from: https://www.worldometers.info/coron avirus/.

6. Ren L-L, Wang Y-M, Wu Z-Q, Xiang Z-C, Guo L, Xu T, et al. Identification of a novel coronavirus causing severe pneumonia in human: a descriptive study. Chin Med J (Engl). 2020;133:101524. https://doi.org/10.1097/cm9.0000000000000722.

7. Wang W, Tang J, Wei F. Updated understanding of the outbreak of 2019 novel coronavirus (2019-nCoV) in Wuhan. China J Med Virol. 2020;92:441-7. https://doi.org/10.1002/jmv. 25689.

8. Graham Carlos W, Dela Cruz CS, Cao B, Pasnick S, Jamil S. Novel Wuhan (2019-NCoV) coronavirus. Am J Respir Crit Care Med. 2020;201:P7-8. https://doi.org/10.1164/rccm.2014P7.

9. Peiris JSM, Guan Y, Yuen KY. Severe acute respiratory syndrome. Nat Med. 2004;10:S88-97. https://doi.org/10.1038/ $\mathrm{nm} 1143$.

10. Lu R, Zhao X, Li J, Niu P, Yang B, Wu H, et al. Genomic characterisation and epidemiology of 2019 novel coronavirus: implications for virus origins and receptor binding. Lancet. 2020;395:565-74. https://doi.org/10.1016/S0140-6736(20) 30251-8. 
11. Hoffmann M, Kleine-Weber H, Krüger N, Müller M, Drosten C, Pöhlmann S. The novel coronavirus 2019 (2019-nCoV) uses the SARS-coronavirus receptor ACE2 and the cellular protease TMPRSS2 for entry into target cells. bioRxiv. 2020. https://doi. org/10.1101/2020.01.31.929042.

12 Yazdanpanah F, Hamblin MR, Rezaei N. The immune system and COVID-19: friend or foe? Life Sci. 2020;256:117900. https://doi. org/10.1016/j.lfs.2020.117900.

13. Sarzi-Puttini P, Giorgi V, Sirotti S, Marotto D, Ardizzone S, Rizzardini G, et al. COVID-19, cytokines and immunosuppression: what can we learn from severe acute respiratory syndrome? Clin Exp Rheumatol. 2020;38:337-42.

14. Hoffmann M, Kleine-Weber H, Schroeder S, Krüger N, Herrler $\mathrm{T}$, Erichsen S, et al. SARS-CoV-2 cell entry depends on ACE2 and TMPRSS 2 and is blocked by a clinically proven protease inhibitor. Cell. 2020;181:271-280 e8. https://doi.org/10.1016/j. cell.2020.02.052.

15. Luan B, Huynh T, Cheng X, Lan G, Wang HR. Targeting proteases for treating COVID-19. J Proteome Res. 2020;19:431626. https://doi.org/10.1021/acs.jproteome.0c00430.

16. Wrapp D, Wang N, Corbett KS, Goldsmith JA, Hsieh CL, Abiona O, et al. Cryo-EM structure of the 2019-nCoV spike in the prefusion conformation. Science. 2020;367:1260-3. https://doi.org/10. 1126/science.abb2507.

17. Li X, Geng M, Peng Y, Meng L, Lu S. Molecular immune pathogenesis and diagnosis of COVID-19. J Pharm Anal. 2020;10:102-8. https://doi.org/10.1016/j.jpha.2020.03.001.

18. Rokni M, Ghasemi V, Tavakoli Z. Immune responses and pathogenesis of SARS-CoV-2 during an outbreak in Iran: comparison with SARS and MERS. Rev Med Virol. 2020;30:e2107. https:// doi.org/10.1002/rmv.2107.

19. Mohamed Khosroshahi L, Rokni M, Mokhtari T, Noorbakhsh F. Immunology, immunopathogenesis and immunotherapeutics of COVID-19; an overview. Int Immunopharmacol. 2021;93:107364. https://doi.org/10.1016/j.intimp.2020.107364.

20 Prompetchara E, Ketloy C, Palaga T. Immune responses in COVID-19 and potential vaccines: lessons learned from SARS and MERS epidemic. Asian Pacific J Allergy Immunol. 2020;38:1-9. https://doi.org/10.12932/AP-200220-0772.

21. Yuan H, Cao X, Ji X, Du F, Zhou X, He J, et al. A current emerging respiratory infection: epidemiological and clinical characteristics, diagnosis and treatments of COVID-19. SSRN Electron J. 2020. https://doi.org/10.2139/ssrn.3551344.

22. Sy F, Ks Y, Zw Y, Cp C, Dy J. A tug-of-war between severe acute respiratory syndrome coronavirus 2 and host antiviral defence: lessons from other pathogenic viruses. Emerg Microbes Infect. 2020;9:558-70. https://doi.org/10.1080/22221751.2020.17366 44.

23. Barnes BJ, Adrover JM, Baxter-Stoltzfus A, Borczuk A, Cools-Lartigue J, Crawford JM, et al. Targeting potential drivers of COVID-19: neutrophil extracellular traps. J Exp Med. 2020;217:e20200652. https://doi.org/10.1084/jem.20200652.

24 Zhou P, Lou Yang X, Wang XG, Hu B, Zhang L, Zhang W, et al. A pneumonia outbreak associated with a new coronavirus of probable bat origin. Nature. 2020;579:270-3. https://doi.org/ 10.1038/s41586-020-2012-7.

25. Wu F, Zhao S, Yu B, Chen YM, Wang W, Song ZG, et al. A new coronavirus associated with human respiratory disease in China. Nature. 2020;579:265-9. https://doi.org/10.1038/ s41586-020-2008-3.

26. Qin C, Zhou L, Hu Z, Zhang S, Yang S, Tao Y, et al. Dysregulation of immune response in patients with COVID-19 in Wuhan. China Clin Infect Dis. 2020;71:762-8. https://doi.org/10.1093/ $\mathrm{cid} / \mathrm{ciaa} 248$.
27. Mahallawi WH, Khabour OF, Zhang Q, Makhdoum HM, Suliman BA. MERS-CoV infection in humans is associated with a pro-inflammatory Th1 and Th17 cytokine profile. Cytokine. 2018;104:8-13. https://doi.org/10.1016/j.cyto.2018.01.025.

28. Wong CK, Lam CWK, Wu AKL, Ip WK, Lee NLS, Chan IHS, et al. Plasma inflammatory cytokines and chemokines in severe acute respiratory syndrome. Clin Exp Immunol. 2004;136:95103. https://doi.org/10.1111/j.1365-2249.2004.02415.x.

29. Giamarellos-Bourboulis EJ, Netea MG, Rovina N, Akinosoglou $\mathrm{K}$, Antoniadou A, Antonakos N, et al. Complex immune dysregulation in COVID-19 patients with severe respiratory failure. Cell Host Microbe. 2020;pii: S1931-3128 (20) 30236-5.

30 Abdulamir A, Hafidh R. The possible immunological pathways for the variable immunopathogenesis of COVID-19 infections among healthy adults, elderly and children. Electron J Gen Med. 2020;17:em202.

31. Dandekar AA, Perlman S. Immunopathogenesis of coronavirus infections: implications for SARS. Nat Rev Immunol. 2005;5:917-27. https://doi.org/10.1038/nri1732.

32. Channappanavar R, Perlman S. Pathogenic human coronavirus infections: causes and consequences of cytokine storm and immunopathology. Semin Immunopathol. 2017;39:529-39. https://doi.org/10.1007/s00281-017-0629-x.

33. Kindler E, Thiel V, Weber F. Interaction of SARS and MERS Coronaviruses with the antiviral interferon response. Adv Virus Res. 2016;96:219-43. https://doi.org/10.1016/bs.aivir.2016.08. 006.

34. de Wit E, van Doremalen N, Falzarano D, Munster VJ. SARS and MERS: recent insights into emerging coronaviruses. Nat Rev Microbiol. 2016;14:523-34. https://doi.org/10.1038/nrmic ro.2016.81.

35. Zumla A, Hui DS, Perlman S. Middle East respiratory syndrome. Lancet. 2015;386:995-1007. https://doi.org/10.1016/S01406736(15)60454-8.

36. Liao M, Liu Y, Yuan J, Wen Y, Xu G, Zhao J, et al. Singlecell landscape of bronchoalveolar immune cells in patients with COVID-19. Nat Med. 2020;26:842-4. https://doi.org/10.1038/ s41591-020-0901-9.

37. Mohamed Khosroshahi L, Rezaei N. Dysregulation of the immune response in coronavirus disease 2019. Cell Biol Int. 2021;45:702-7. https://doi.org/10.1002/cbin.11517.

38. Garcia KC. Dual arms of adaptive immunity: division of labor and collaboration between B and T cells. Cell. 2019;179:3-7. https://doi.org/10.1016/j.cell.2019.08.022.

39. Mahmoodpoor A, Nader ND. Immune responses to the novel coronavirus-2: friend or foe? Immunol Invest. 2020;1-3. https:// doi.org/10.1080/08820139.2020.1795191.

40. Liu WJ, Zhao M, Liu K, Xu K, Wong G, Tan W, et al. T-cell immunity of SARS-CoV: implications for vaccine development against MERS-CoV. Antiviral Res. 2017;137:82-92. https://doi. org/10.1016/j.antiviral.2016.11.006.

41. Rokni M, Hamblin MR, Rezaei N. Cytokines and COVID-19: friends or foes? Hum Vaccines Immunother. 2020;16:2363-5. https://doi.org/10.1080/21645515.2020.1799669.

42. Chowdhury MA, Hossain N, Kashem MA, Shahid MA, Alam A. Immune response in COVID-19: a review. J Infect Public Health. 2020;S1876-0341(20):30567. https://doi.org/10.1016/j. jiph.2020.07.001.

43. García LF. Immune response, inflammation, and the clinical spectrum of COVID-19. Front Immunol. 2020;11:1441. https:// doi.org/10.3389/fimmu.2020.01441.

44. Du L, He Y, Zhou Y, Liu S, Zheng BJ, Jiang S. The spike protein of SARS-CoV-a target for vaccine and therapeutic development. Nat Rev Microbiol. 2009;7:226-36. https://doi.org/10.1038/ nrmicro2090. 
45. Lee N, Chan PKS, Ip M, Wong E, Ho J, Ho C, et al. Anti-SARSCoV IgG response in relation to disease severity of severe acute respiratory syndrome. J Clin Virol. 2006;35:179-84. https://doi. org/10.1016/j.jcv.2005.07.005.

46. Stadlbauer D, Amanat F, Chromikova V, Jiang K, Strohmeier S, Arunkumar GA, et al. SARS-CoV-2 seroconversion in humans: a detailed protocol for a serological assay, antigen production, and test setup. Curr Protoc Microbiol. 2020;57:e100. https://doi. org/10.1002/cpmc.100.

47. Li G, Fan Y, Lai Y, Han T, Li Z, Zhou P, et al. Coronavirus infections and immune responses. J Med Virol. 2020;92:424-32. https://doi.org/10.1002/jmv.25685.

48. Ju B, Zhang Q, Ge X, Wang R, Yu J, Shan S, et al. Potent human neutralizing antibodies elicited by SARS-CoV-2 infection. bioRxiv. 2020;2020.03.21.990770. https://doi.org/10.1101/2020. 03.21.990770.

49. Long QX, Liu BZ, Deng HJ, Wu GC, Deng K, Chen YK, et al. Antibody responses to SARS-CoV-2 in patients with COVID-19. Nat Med. 2020;26:845-8. https://doi.org/10.1038/ s41591-020-0897-1.

50. Wen W, Su W, Tang H, Le W, Zhang X, Zheng Y, et al. Immune cell profiling of COVID-19 patients in the recovery stage by single-cell sequencing. Cell Discov. 2020;6:31. https://doi.org/ 10.1038/s41421-020-0168-9.

51. Okba NMA, Müller MA, Li W, Wang C, Geurtsvankessel CH, Corman VM, et al. Severe acute respiratory syndrome coronavirus 2-specific antibody responses in coronavirus disease patients. Emerg Infect Dis. 2020;26:1478-88. https://doi.org/10.3201/ eid2607.200841.

52. Wölfel R, Corman VM, Guggemos W, Seilmaier M, Zange S, Müller MA, et al. Virological assessment of hospitalized patients with COVID-2019. Nature. 2020;581:465-9. https://doi.org/10. 1038/s41586-020-2196-x.

53. Zhao J, Yuan Q, Wang H, Liu W, Liao X, Su Y, et al. Antibody responses to SARS-CoV-2 in patients with novel coronavirus disease 2019. Clin Infect Dis. 2020;71:2027-34. https://doi.org/ 10.1093/cid/ciaa344.

54. Li K, Chen D, Chen S, Feng Y, Chang C, Wang Z, et al. Radiographic findings and other predictors in adults with Covid-19. medRxiv. 2020. https://doi.org/10.1101/2020.03.23.20041673.

55. Zhou F, Yu T, Du R, Fan G, Liu Y, Liu Z, et al. Clinical course and risk factors for mortality of adult inpatients with COVID19 in Wuhan, China: a retrospective cohort study. Lancet. 2020;395:1054-62. https://doi.org/10.1016/S0140-6736(20) 30566-3.

56. Zhang L, Zhang F, Yu W, He T, Yu J, Yi CE, et al. Antibody responses against SARS coronavirus are correlated with disease outcome of infected individuals. J Med Virol. 2006;78:1-8. https://doi.org/10.1002/jmv.20499.

57. Taylor A, Foo SS, Bruzzone R, Vu Dinh L, King NJC, Mahalingam $\mathrm{S}$. Fc receptors in antibody-dependent enhancement of viral infections. Immunol Rev. 2015;268:340-64. https://doi.org/ 10.1111/imr.12367.

58. Yip MS, Leung NHL, Cheung CY, Li PH, Lee HHY, Daëron $\mathrm{M}$, et al. Antibody-dependent infection of human macrophages by severe acute respiratory syndrome coronavirus. Virol J. 2014;11:82. https://doi.org/10.1186/1743-422X-11-82.

59. Liu L, Wei Q, Lin Q, Fang J, Wang H, Kwok H, et al. Anti-spike $\mathrm{IgG}$ causes severe acute lung injury by skewing macrophage responses during acute SARS-CoV infection. JCI insight. 2019;4:e123158. https://doi.org/10.1172/jci.insight.123158.

60. Wan Y, Shang J, Sun S, Tai W, Chen J, Geng Q, et al. Molecular mechanism for antibody-dependent enhancement of coronavirus entry. J Virol. 2020;94:e02015-e2019. https://doi.org/ 10.1128/jvi.02015-19.
61. Yang L, Liu S, Liu J, Zhang Z, Wan X, Huang B, et al. COVID19: immunopathogenesis and Immunotherapeutics. Signal Transduct Target Ther. 2020;5:128. https://doi.org/10.1038/ s41392-020-00243-2.

62. Vabret N, Britton GJ, Gruber C, Hegde S, Kim J, Kuksin M, et al. Immunology of COVID-19: current state of the science. Immunity. 2020;52:910-41. https://doi.org/10.1016/j.immuni. 2020.05.002.

63. Sherina N, Piralla A, Du L, Wan H, Kumagai-Braesch M, Andréll J, et al. Persistence of SARS-CoV-2-specific B and T cell responses in convalescent COVID-19 patients 6-8 months after the infection. Med. 2021;2(281-295):e4. https://doi.org/ 10.1016/j.medj.2021.02.001

64. Oh HLJ, Gan SKE, Bertoletti A, Tan YJ. Understanding the T cell immune response in SARS coronavirus infection. Emerg Microbes Infect. 2012;1:e23. https://doi.org/10.1038/emi.2012. 26.

65. Shin HS, Kim Y, Kim G, Lee JY, Jeong I, Joh JS, et al. Immune responses to Middle East respiratory syndrome coronavirus during the acute and convalescent phases of human infection. Clin Infect Dis. 2019;68:984-92. https://doi.org/10.1093/cid/ ciy595.

66. Russell B, Moss C, George G, Santaolalla A, Cope A, Papa S, et al. Associations between immune-suppressive and stimulating drugs and novel COVID-19-a systematic review of current evidence. Ecancermedicalscience. 2020;14:1022. https://doi.org/ 10.3332/ecancer.2020.1022.

67. Zheng HY, Zhang M, Yang CX, Zhang N, Wang XC, Yang XP, et al. Elevated exhaustion levels and reduced functional diversity of $\mathrm{T}$ cells in peripheral blood may predict severe progression in COVID-19 patients. Cell Mol Immunol. 2020;17:541-3. https:// doi.org/10.1038/s41423-020-0401-3.

68. Pedersen SF, Ho YC. SARS-CoV-2: a storm is raging. J Clin Invest. 2020;130:2202-5. https://doi.org/10.1172/JCI137647.

69. Chen G, Wu D, Guo W, Cao Y, Huang D, Wang H, et al. Clinical and immunological features of severe and moderate coronavirus disease 2019. J Clin Invest. 2020;130:2620-9. https://doi.org/10. 1172/JCI137244.

70. Gu J, Gong E, Zhang B, Zheng J, Gao Z, Zhong Y, et al. Multiple organ infection and the pathogenesis of SARS. J Exp Med. 2005;202:415-24. https://doi.org/10.1084/jem.20050828.

71. Assiri A, Al-Tawfiq JA, Al-Rabeeah AA, Al-Rabiah FA, AlHajjar S, Al-Barrak A, et al. Epidemiological, demographic, and clinical characteristics of 47 cases of Middle East respiratory syndrome coronavirus disease from Saudi Arabia: a descriptive study. Lancet Infect Dis. 2013;13:752-61. https://doi.org/10. 1016/S1473-3099(13)70204-4.

72. Chu H, Zhou J, Wong BHY, Li C, Chan JFW, Cheng ZS, et al. Middle East respiratory syndrome coronavirus efficiently infects human primary $\mathrm{T}$ lymphocytes and activates the extrinsic and intrinsic apoptosis pathways. J Infect Dis. 2016;213:904-14. https://doi.org/10.1093/infdis/jiv380.

73. Chen N, Zhou M, Dong X, Qu J, Gong F, Han Y, et al. Epidemiological and clinical characteristics of 99 cases of 2019 novel coronavirus pneumonia in Wuhan, China: a descriptive study. Lancet. 2020;395:507-13. https://doi.org/10.1016/S01406736(20)30211-7.

74. Wang D, Hu B, Hu C, Zhu F, Liu X, Zhang J, et al. Clinical characteristics of 138 hospitalized patients with 2019 novel coronavirus-infected pneumonia in Wuhan, China. JAMA - J Am Med Assoc. 2020;323:1061-9. https://doi.org/10.1001/jama. 2020.1585.

75. Guihot A, Litvinova E, Autran B, Debré P, Vieillard V. Cellmediated immune responses to COVID-19 infection. Front Immunol. 2020;11:1662. https://doi.org/10.3389/fimmu.2020. 01662. 
76. Zhang W, Zhao Y, Zhang F, Wang Q, Li T, Liu Z, et al. The use of anti-inflammatory drugs in the treatment of people with severe coronavirus disease 2019 (COVID-19): the experience of clinical immunologists from China. Clin Immunol. 2020;214:108393. https://doi.org/10.1016/j.clim.2020.108393.

77. Arruvito L, Payaslián F, Baz P, Podhorzer A, Billordo A, Pandolfi $\mathrm{J}$, et al. Identification and clinical relevance of naturally occurring human CD8 + HLA-DR + regulatory T cells. J Immunol. 2014;193:4469-76. https://doi.org/10.4049/jimmunol.14014 90.

78. Diao B, Wang C, Tan Y, Chen X, Liu Y, Ning L, et al. Reduction and functional exhaustion of T cells in patients with coronavirus disease 2019 (COVID-19). Front Immunol. 2020;11:827. https:// doi.org/10.3389/fimmu.2020.00827.

79. Xu Z, Shi L, Wang Y, Zhang J, Huang L, Zhang C, et al. Pathological findings of COVID-19 associated with acute respiratory distress syndrome. Lancet Respir Med. 2020;8:420-2. https:// doi.org/10.1016/S2213-2600(20)30076-X.

80. He F, Deng Y, Li W. Coronavirus disease 2019: what we know? J Med Virol. 2020;92:719-25. https://doi.org/10.1002/jmv.25766.

81. Chen J, Lau YF, Lamirande EW, Paddock CD, Bartlett JH, Zaki $\mathrm{SR}$, et al. Cellular immune responses to severe acute respiratory syndrome coronavirus (SARS-CoV) infection in senescent BALB/c mice: CD4+ T cells are important in control of SARSCoV infection. J Virol. 2010;84:1289-301. https://doi.org/10. 1128/jvi.01281-09.

82. Tang Y, Liu J, Zhang D, Xu Z, Ji J, Wen C. Cytokine storm in COVID-19: the current evidence and treatment strategies. Front Immunol. 2020;11:1708. https://doi.org/10.3389/fimmu.2020. 01708.

83. Tisoncik JR, Korth MJ, Simmons CP, Farrar J, Martin TR, Katze MG. Into the eye of the cytokine storm. MicrobiolMolBiol Rev. 2012;76:16-32. https://doi.org/10.1128/mmbr.05015-11.

84. Ragab D, Salah Eldin H, Taeimah M, Khattab R, Salem R. The COVID-19 cytokine storm; what we know so far. Front Immunol. 2020;11:1446. https://doi.org/10.3389/fimmu.2020.01446.

85. Ruan Q, Yang K, Wang W, Jiang L, Song J. Clinical predictors of mortality due to COVID-19 based on an analysis of data of 150 patients from Wuhan. China Intensive Care Med. 2020;46:846-8. https://doi.org/10.1007/s00134-020-05991-x.

86. Gao Y, Li T, Han M, Li X, Wu D, Xu Y, et al. Diagnostic utility of clinical laboratory data determinations for patients with the severe COVID-19. J Med Virol. 2020;92:791-6. https://doi.org/ 10.1002/jmv.25770.

87. Chen L, Liu HG, Liu W, Liu J, Liu K, Shang J, et al. Analysis of clinical features of 29 patients with, novel coronavirus pneumonia. Zhonghua Jie He He Hu Xi Za Zhi. 2020;43:E005. https:// doi.org/10.3760/CMA.J.ISSN.1001-0939.2020.0005.

88. Sun D, Li H, Lu XX, Xiao H, Ren J, Zhang FR, et al. Clinical features of severe pediatric patients with coronavirus disease 2019 in Wuhan: a single center's observational study. World J Pediatr. 2020;16:251-9. https://doi.org/10.1007/s12519-020-00354-4.

89. Li J, Guo M, Tian X, Wang X, Yang X, Wu P, et al. Virus-host interactome and proteomic survey reveal potential virulence factors influencing SARS-CoV-2 pathogenesis. Med (N Y). 2020. https://doi.org/10.1016/j.medj.2020.07.002.

90. Xu X, Han M, Li T, Sun W, Wang D, Fu B, et al. Effective treatment of severe COVID-19 patients with tocilizumab. Proc Natl Acad Sci U S A. 2020;117:10970-5. https://doi.org/10.1073/ pnas.2005615117.

91. Tay MZ, Poh CM, Rénia L, MacAry PA, Ng LFP. The trinity of COVID-19: immunity, inflammation and intervention. Nat Rev Immunol. 2020;20:363-74. https://doi.org/10.1038/ s41577-020-0311-8.
92. Coronavirus Incubation Period (COVID-19)-Worldometer [Internet]. [cited 2021 Apr 19]. Available from: https://www.world ometers.info/coronavirus/coronavirus-incubation-period/.

93. Ansariniya H, Seifati SM, Zaker E, Zare F. Comparison of immune response between SARS, MERS, and COVID-19 infection, perspective on vaccine design and development. Biomed Res Int. 2021;2021:8870425. https://doi.org/10.1155/2021/88704 25.

94. Weisblum Y, Schmidt F, Zhang F, DaSilva J, Poston D, Lorenzi JCC, et al. Escape from neutralizing antibodies by SARS-CoV-2 spike protein variants. Elife. 2020;9:e61312. https://doi.org/10. 7554/eLife.61312.

95. Ziegler CGK, Allon SJ, Nyquist SK, Mbano IM, Miao VN, Tzouanas CN, et al. SARS-CoV-2 receptor ACE2 is an interferon-stimulated gene in human airway epithelial cells and is detected in specific cell subsets across tissues. Cell. 2020;181(1016-1035):e19. https://doi.org/10.1016/j.cell.2020. 04.035 .

96. Fung TS, Liu DX. Human coronavirus: host-pathogen interaction. Annu Rev Microbiol. 2019;73:529-57. https://doi.org/10. 1146/annurev-micro-020518-115759.

97. Channappanavar R, Fehr AR, Vijay R, Mack M, Zhao J, Meyerholz DK, et al. Dysregulated type I interferon and inflammatory monocyte-macrophage responses cause lethal pneumonia in SARS-CoV-infected mice. Cell Host Microbe. 2016;19:181-93. https://doi.org/10.1016/j.chom.2016.01.007.

98. Nelemans T, Kikkert M. Viral innate immune evasion and the pathogenesis of emerging RNA virus infections. Viruses. 2019;11:961. https://doi.org/10.3390/v11100961.

99. Jauregui AR, Savalia D, Lowry VK, Farrell CM, Wathelet MG. Identification of residues of SARS-CoV nsp1 that differentially affect inhibition of gene expression and antiviral signaling. PLoS ONE. 2013;8:e62416. https://doi.org/10.1371/journal.pone. 0062416.

100. Bordi L, Nicastri E, Scorzolini L, Di Caro A, Capobianchi MR, Castilletti C, et al. Differential diagnosis of illness in patients under investigation for the novel coronavirus (SARS-CoV-2), Italy, February 2020. Eurosurveillance. 2020;25:2000170. https://doi.org/10.2807/1560-7917.ES.2020.25.8.2000170.

101. Ben Addi A, Lefort A, Hua X, Libert F, Communi D, Ledent C, et al. Modulation of murine dendritic cell function by adenine nucleotides and adenosine: involvement of the A2B receptor. Eur J Immunol. 2008;38:1610-20. https://doi.org/10.1002/eji.20073 7781.

102. Snijder EJ, van der Meer Y, Zevenhoven-Dobbe J, Onderwater JJM, van der Meulen J, Koerten HK, et al. Ultrastructure and origin of membrane vesicles associated with the severe acute respiratory syndrome coronavirus replication complex. J Virol. 2006;80:5927-40. https://doi.org/10.1128/jvi.02501-05.

103. Knoops K, Kikkert M, Van Den Worm SHE, Zevenhoven-Dobbe JC, Van Der Meer Y, Koster AJ, et al. SARS-coronavirus replication is supported by a reticulovesicular network of modified endoplasmic reticulum. PLoS Biol. 2008;6:e226. https://doi.org/ 10.1371/journal.pbio.0060226.

104. Hu Y, Li W, Gao T, Cui Y, Jin Y, Li P, et al. The severe acute respiratory syndrome coronavirus nucleocapsid inhibits type I interferon production by interfering with TRIM25-mediated RIG-I ubiquitination. J Virol. 2017;91:e02143-e2216. https://doi. org/10.1128/jvi.02143-16.

105. Frieman M, Yount B, Heise M, Kopecky-Bromberg SA, Palese P, Baric RS. Severe acute respiratory syndrome coronavirus ORF6 antagonizes STAT1 function by sequestering nuclear import factors on the rough endoplasmic reticulum/golgi membrane. $\mathrm{J}$ Virol. 2007;81:9812-24. https://doi.org/10.1128/jvi.01012-07.

106. Kopecky-Bromberg SA, Martínez-Sobrido L, Frieman M, Baric RA, Palese P. Severe acute respiratory syndrome coronavirus 
open reading frame (ORF) 3b, ORF 6, and nucleocapsid proteins function as interferon antagonists. J Virol. 2007;81:548-57. https://doi.org/10.1128/jvi.01782-06.

107. Chafekar A, Fielding BC. MERS-CoV: understanding the latest human coronavirus threat. Viruses. 2018;10:93. https://doi.org/ 10.3390/v10020093.

108. Yuen CK, Lam JY, Wong WM, Mak LF, Wang X, Chu H, et al. SARS-CoV-2 nsp13, nsp14, nsp15 and orf6 function as potent interferon antagonists. Emerg Microbes Infect. 2020;9:1418-28. https://doi.org/10.1080/22221751.2020.1780953.

109. Shi C-S, Qi H-Y, Boularan C, Huang N-N, Abu-Asab M, Shelhamer JH, et al. SARS-coronavirus open reading frame$9 \mathrm{~b}$ suppresses innate immunity by targeting mitochondria and the MAVS/TRAF3/TRAF6 signalosome. J Immunol. 2014;193:3080-9. https://doi.org/10.4049/jimmunol.1303196.

110. Totura AL, Whitmore A, Agnihothram S, Schäfer A, Katze MG, Heise MT, et al. Toll-like receptor 3 signaling via TRIF contributes to a protective innate immune response to severe acute respiratory syndrome coronavirus infection. MBio. 2015;6:e00638-e715. https://doi.org/10.1128/mBio.00638-15.

111. Li SW, Wang CY, Jou YJ, Huang SH, Hsiao LH, Wan L, et al. SARS coronavirus papain-like protease inhibits the TLR7 signaling pathway through removing Lys63-linked polyubiquitination of TRAF3 and TRAF6. Int J Mol Sci. 2016;17:678. https://doi. org/10.3390/ijms17050678.

112 Al-Qahtani AA, Lyroni K, Aznaourova M, Tseliou M, AlAnazi MR, Al-Ahdal MN, et al. Middle east respiratory syndrome corona virus spike glycoprotein suppresses macrophage responses via DPP4-mediated induction of IRAK-M and PPAR $\gamma$. Oncotarget. 2017;8:9053-66. https://doi.org/10.18632/oncot arget. 14754.

113. Zheng M, Gao Y, Wang G, Song G, Liu S, Sun D, et al. Functional exhaustion of antiviral lymphocytes in COVID-19 patients.
Cell Mol Immunol. 2020;17:533-5. https://doi.org/10.1038/ s41423-020-0402-2.

114. Cifaldi L, Prencipe G, Caiello I, Bracaglia C, Locatelli F, De Benedetti F, et al. Inhibition of natural killer cell cytotoxicity by interleukin-6: implications for the pathogenesis of macrophage activation syndrome. Arthritis Rheumatol. 2015;67:3037-46. https://doi.org/10.1002/art.39295.

115. Frieman M, Heise M, Baric R. SARS coronavirus and innate immunity. Virus Res. 2008;133:101-12. https://doi.org/10. 1016/j.virusres.2007.03.015.

116. Zhou R, To KKW, Wong YC, Liu L, Zhou B, Li X, et al. Acute SARS-CoV-2 infection impairs dendritic cell and T cell responses. Immunity. 2020;53(864-877):e5. https://doi.org/10. 1016/j.immuni.2020.07.026.

117. Wilk AJ, Rustagi A, Zhao NQ, Roque J, Martínez-Colón GJ, McKechnie JL, et al. A single-cell atlas of the peripheral immune response in patients with severe COVID-19. Nat Med. 2020;26:1070-6. https://doi.org/10.1038/s41591-020-0944-y.

118. Zhou D, Dejnirattisai W, Supasa P, Liu C, Mentzer AJ, Ginn $\mathrm{HM}$, et al. Evidence of escape of SARS-CoV-2 variant B.1.351 from natural and vaccine-induced sera. Cell. 2021;S00928674:00226-9. https://doi.org/10.1016/j.cell.2021.02.037.

119. Quast I, Tarlinton D. B cell memory: understanding COVID-19. Immunity. 2021;54:205-10. https://doi.org/10.1016/j.immuni. 2021.01.014.

Publisher's note Springer Nature remains neutral with regard to jurisdictional claims in published maps and institutional affiliations. 